\title{
Mobile telephones as public sphere in peri-urban Papua New Guinea
}

Téléphones mobiles, un domaine public dans la Papouasie Nouvelle-Guinée périurbaine

\section{David Lipset}

\section{(2) OpenEdition}

\section{Journals}

Electronic version

URL: http://journals.openedition.org/jso/7835

DOI: $10.4000 /$ jso.7835

ISSN: $1760-7256$

\section{Publisher}

Société des océanistes

\section{Printed version}

Date of publication: 15 December 2017

Number of pages: 195-208

ISSN: 0300-953x

\section{Electronic reference}

David Lipset, "Mobile telephones as public sphere in peri-urban Papua New Guinea", Journal de la Société des Océanistes [Online], 144-145 | 2017, Online since 15 December 2019, connection on 15 March 2021. URL: http://journals.openedition.org/jso/7835 ; DOI: https://doi.org/10.4000/jso.7835

\section{(c) $(9)$}

Journal de la société des océanistes est mis à disposition selon les termes de la Licence Creative Commons Attribution - Pas d'Utilisation Commerciale - Pas de Modification 4.0 International. 


\title{
Mobile telephones as public sphere in peri-urban Papua New Guinea
}

by

\author{
David LIPSET ${ }^{*}$
}

\begin{abstract}
In urban Papua New Guinea (PNG), attitudes about and uses of mobile phones may be construed as a kind of a Habermasian public sphere, albeit one whose moral space and discourse is characteristically Melanesian. That is to say, the notion of "public" is not sharply differentiated either from the state or the private domain. In PNG, the citizenry assess mobile phone use not to only criticize the legitimacy of the postcolonial state, but also complain about the moral failings of the nation. Meanwhile, as they do so, they make calls for legitimate purposes, purposes that help them attain particularistic goals and assert particularistic values, both old and new.
\end{abstract}

KeYworDs: public sphere, Habermas, mobile phones, Papua New Guinea, Wewak

Habermas (1991) argued that a "bourgeois public sphere" emerged along with the rise of "network institutions" like newspapers, town squares and coffeehouses in early, modern cities in Britain and France. In this era, unofficial, middle-class voices, in criticism of the failures and shortcomings of state authority, began to assert and advocate "public opinion" by which they sought to compel political change. ${ }^{1}$ In this article, I want to suggest that attitudes about and uses of mobile phones in urban Papua New Guinea (PNG) may be construed as a kind of a public sphere, albeit one whose moral space and

\section{RÉSUMÉ}

Dans les villes de Papouasie Nouvelle-Guinée, l'utilisation du téléphone portable et l'opinion que les gens en ont peuvent être compris comme une sorte d'espace social habermassien, même sìl s'agit d'un espace et d'un discours moral typiquement mélanesien. Autrement dit, la notion de "public" nest ici pas très différente de ce qu'est l'État ou le domaine privé. En PNG, les citoyens utilisent le téléphone portable non seulement pour critiquer la légitimité de l'État postcolonial, mais aussi pour se plaindre des manquements moraux de la nation. Ce faisant, ils passent aussi des appels pour des raisons légitimes, raisons qui leur permettent d'atteindre des buts précis, en affirmant des valeurs précises, anciennes ou nouvelles.

Mots-clés : domaine public, Habermas, téléphones mobiles, Papouasie Nouvelle-Guinée, Wewak

discourse is characteristically Melanesian. ${ }^{2}$ That is to say, the notion of "public" is not sharply differentiated either from the state or the private domain. If the Habermasian "public sphere" pitted the voices of European society against the state, in PNG, the citizenry discuss the uses to which mobile phones are put not to only criticize the legitimacy of their postcolonial state, but also to complain about the moral failings of the nation. Meanwhile, as they do so, they make calls for legitimate purposes, purposes that help them attain particularistic goals and assert particularistic values, both old and new.

1. Habermas went on to note that the critical capacity of the "public sphere" subsequently deteriorated as capitalism developed.

2. See Myerson 2001, on Heidegger, Habermas and mobile phones.

* University of Minnesota, lipse001@umn.edu 
Instead of asking about the extent to which mobile phones transform society in this corner of the developing world by making it modern, or instead of focusing on how they are contributing to progress in any number of domains of social life, which is the orientation of a great deal of the research that has been done on the introduction of new social technology (Rashid and Elder, 2009: 2-3), this article explores what mobile phones reveals about the problem of legitimacy in a segment of peri-urban society in PNG. That is, I develop a domestication thesis introduced in an earlier paper on mobile phones (Lipset 2013) in which I argued that while mobile telephony has enabled elements classically associated with modern personhood, such as space-time compression and the subject-centered voice, it has also enabled kinship solidarity and conflict expressed in pre-existing idioms and values. Now, I want to argue that some of the most important contradictions of the postcolonial condition in peri-urban PNG adhere to mobile phones and mobile telephony, contradictions that call the legitimacy of the nation-state into question.

I first discuss attitudes, positive and negative, that Papua New Guineans hold about their nation-state, by way of setting a broader framework for my ensuing discussion of mobile phones. I will then introduce the ethnographic setting, the city of Wewak, its peri-urban communities and a particular ethnic or tribal group, who call themselves Murik, that I will use as my exemplar in this article. Next, I discuss attitudes about mobile phones expressed by peri-urban Murik that concern the legitimacy of the nation-state. Lastly, I will analyze ethnographic data on mobile phone use in one peri-urban household. In conclusion, I shall argue that mobile phones as deployed and evaluated by this group at least may be seen to express some of the contradictions of modernity in contemporary PNG.

\section{A contradictory polity}

On the one hand, people express unbridled pride in themselves as Papua New Guineans in the contexts of international athletics or during annual celebrations of independence when they swan about in polos and dresses that bear the nation's bright colors (red, black and yellow) and insignia (the Southern Cross and a sihouetted raggiana bird of paradise). And, as Robert Foster showed us so brilliantly, they portray themselves in banal ways in and through consumption practices, when, for example, they buy and drink cans of pop and beer that are emblazoned with corporate logos consisting of imagery of the nation (2002).
However, on the other, they criticize the nation for lacking temporal and moral discipline. Nothing happens on schedule but only on unpredictable and unreliable "Papua New Guinea time." Young men chase women, drink, play cards and do not mind elders. Middle-class elites are greedy and ignore village kin (Martin, 2013). All of which is to say that they see the nation, in which they occasionally take such pride, as beset by rampant individualism.

Their views of the state are no less contradictory. Citizens regularly flock to the polls to vote at all levels of their democracy, which, whatever degree of cynicism they may do so, surely affirms its legitimacy. However, they subject the moral integrity of the state to the most scathing criticism in everyday life. They accuse politicians of corruption, misappropriation of funds and resources, nepotism/patronage and for being grossly incompetent. They reproach leadership for being self-indulgent and self-seeking, albeit in Melanesian terms. Instead of adhering to universalist values, they object to their particularism, provincialism and primordialism. One of the main complaints about and accusations leveled against politicians and bureaucrats is that instead of operating according to bureaucratic rules, they employ the wantok system in which they favor kin and tribesmen with resources (Tokpisin: ol iwokim sistem). Worse yet, they are said to fail at the building and maintenance of infrastructure, not to mention the provision of basic services for less educated, rural folk, called grass roots in PNG. Schools are underfunded. Healthcare is inadequate. Power and water frequently go out. Roads, which are few and far between in the country, are neither maintained nor secure.

If the legitimacy of the nation-state is open to question, in part because of allegations of nepotism, the citizenry nevertheless set their moral compass in normative relations with kin and a sense of place. There is, in other words, a strong and pervasive sentiment of attachment to smallscale community, ${ }^{3}$ with all of the suspicion of the other that such particularism would imply. This committment to "private" society, I must insist, is not only symptomatic of the ongoing strength of primordialism in the country, it expresses a lack of moral conviction in the nation-state.

While debate about contemporary order goes on in rural villages, it is centered in cities where the daily presence of the nation-state is more thoroughly experienced. The question is, where is critical public opinion formulated and debated in urban settings in PNG? Where are the coffee shops and so forth, where people may gather and argue? The "public sphere" is growing in urban PNG, to be sure. It is heard on "Talkback," a daily call-in show 


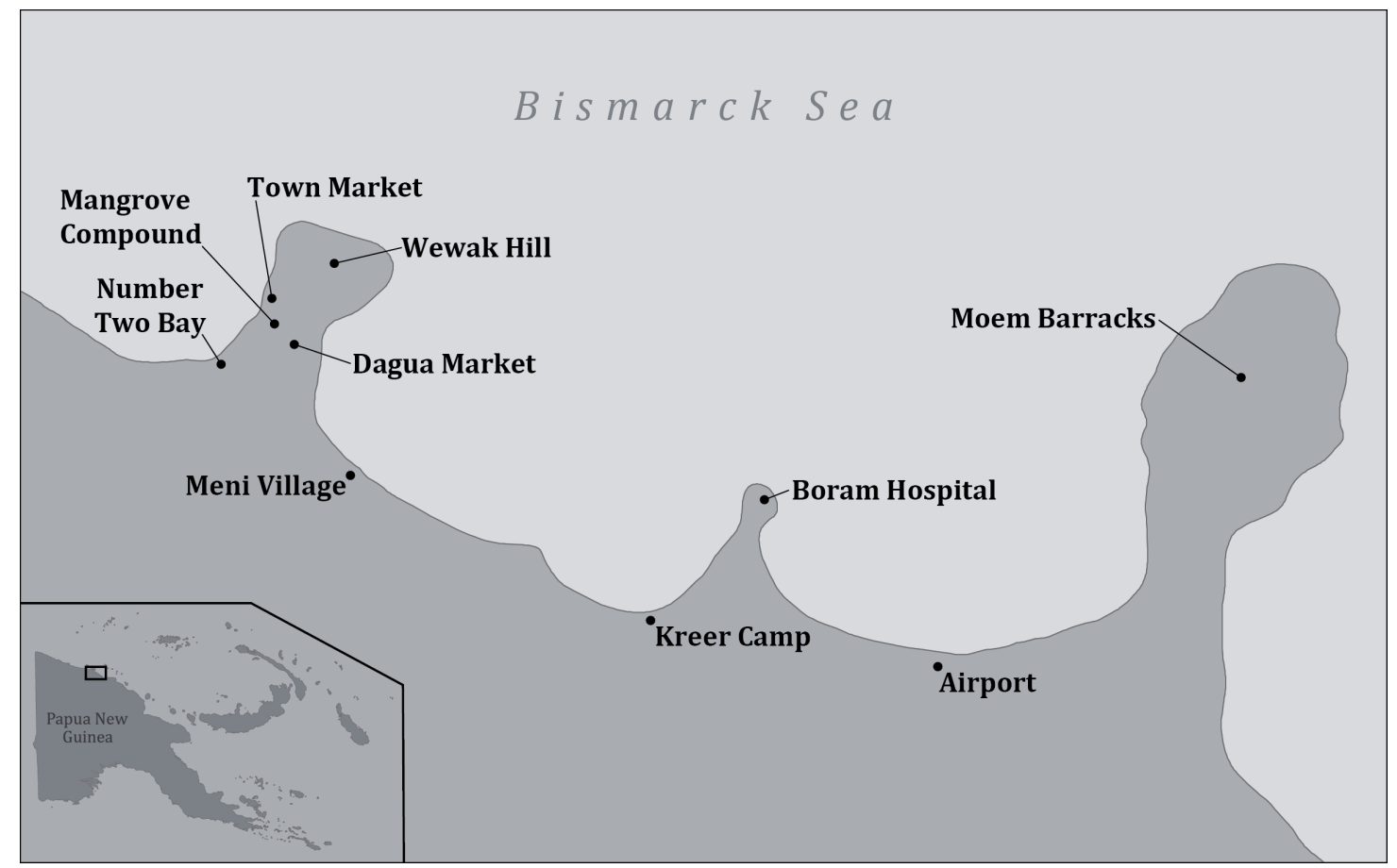

Figure 1. - Map of Wewak (C David Lipset)

broadcast by the National Broadcast Corporation, in the press and on Facebook (Daalsgard, 2016). But, at least since 2007 when mobile phones began to be commonplace in the country, it is also expressed in mobile phone use and in talk about about mobile telephones. Following Castells' point that social technology does not transform society but rather "is society" (2007: 3), mobile phones are objects about which peri-urban Papua New Guineans contest the legitimacy of the nation-state and in this sense, they have come to constitute a kind of Habermasian "public sphere."

\section{Wewak, a provincial town}

The ethnographic setting of this article is a harbor town on the northcoast of PNG. Well known to WW II historians as one of the sites of Japanese surrender in September 1945 (Fleetwood 1984), Wewak is built along a couple of bays divided by several small peninsulas (fig.1). Customary landowners "sold" land for coconut plantations to early German colonials who established the town during the early 20th century. Under Australian colonial rule, the town subsequently became a regional administrative center. Today, its population, which has grown considerably since Independence in 1975, fluctuates around $35,000 .^{4}$
The town occupies a narrow band of flat land along the ocean and up the foothills of a coastal range a short distance inland. Its center is a small peninsula with a shopping center, a wharf and Wewak Hill at the tip. About two miles and half to the east of the town center is another peninsula on which the badly dilapidated Boram Hospital is located, and nearby is a small, one-runway airport, an important link to the rest of country. Another couple of miles further along the coast road to the east, a large peninsula juts into the ocean. Here, Moem Barracks houses the second Royal Pacific Island Regiment, consisting of two battalions of PNGDF infantry (Sinclair, 1992).

The capital of the East Sepik Province, Wewak is is also the regional seat of the Roman Catholic Diocese (founded in 1911) and the Seventh Day Adventists (founded in 1949). In addition to the two missions, as well as many other churches, there are two government centers in town, one for the provincial assembly and the other for its administrative offices. There is also a federal courthouse, an office building for the police and a jail. Wewak is also the central market town in the region, however little industry is based here, other than a tuna cannery, a sawmill and coffee, vanilla and cocoa buyers. The town has two wharfs, a small public one adjacent to its large, main bay in which a handful foreign tuna trawlers are constantly at anchor, and a second, private one 


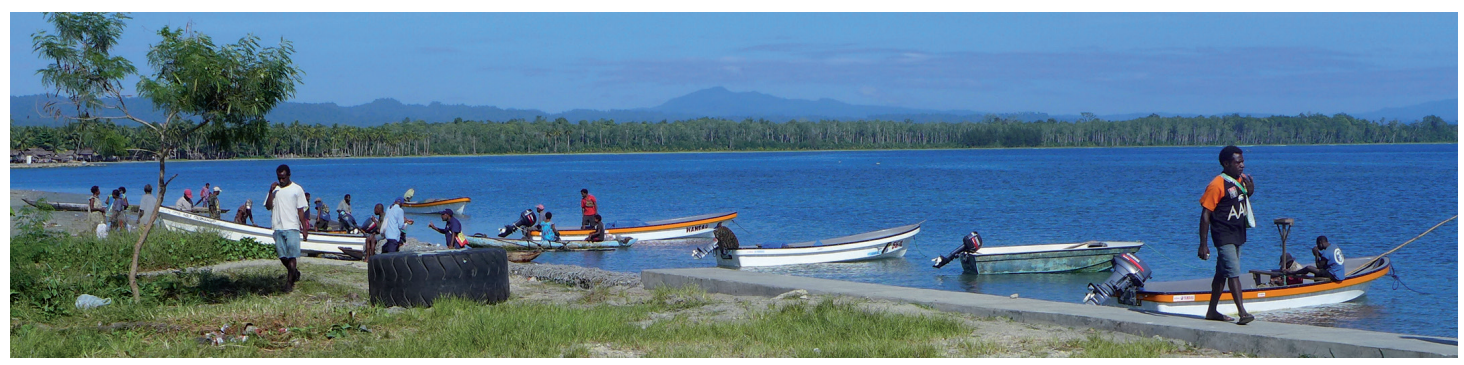

Figure 2. - Wewak, marine transportation hub of the East Sepik Province, 2014 (@ David Lipset)

built and operated by the South Pacific Tuna Co. (Sullivan, 2010).

On one of three roads, provincial traffic motors into town hauling Sepik villagers with fresh produce, coffee, cocoa and copra to sell to urban buyers. The only other access to Wewak from elsewhere in the country, however, is by air or sea. The beaches at both ends of the main street are landing and launching points for the many "banana boats," the 18-23 foot, outboard powered vessels that have become standard across the Pacific, that transport passengers to town from the offshore islands or along the north coast (fig. 2). Buses and private transportation link the town together (fig. 3). As of 2014, taxi service was limited.

From a Habermasian perspective, the public sphere in PNG in general, and in Wewak in particular, where rational debate might take place, was minimal. There are a handful of hotels, with bars and restaurants clustered by the airport and on Wewak Hill. ${ }^{5}$ Today, the latter area is a bastion of middle-class comfort and security, complete with tennis courts and "yacht club" (Gewertz and Errington, 1999) but I would not contend that the hotel eateries, which are frequently by a steady trickle of EuroAmerican and Japanese tourists, Australian mining engineers and military as well as Papua New Guineans on business vouchers, offer themselves up as a public sphere. Newspapers, it is true, are flown in from Port Moresby every morning by Air Niugini and are avidly read. But notably, they are not sold in the hotels. Radio newscasts on the National Broadcasting Company are closely attended to. The town's one movie theater closed down in the 1980s and was replaced by a bulk outlet store and South Pacific beer dispensary owned and operated by the Tjoeng family, under the auspices of their business arm, Garamut Pty Ltd.

Basically, the main public sphere in Wewak is a shopping area that consists of one street lined on both sides with window-less, singlestory buildings, mainly dark, overstocked trade stores owned by a handful of Chinese families, mixed with a couple of big supermarkets, Tang Mow and a store owned by Rimbunan Hijau, a Malaysian company that has been clear-cutting virgin timber stands throughout the country for the past two decades in less than legitimate circumstances (Filer, 2013). The street also hosts several banks, a pharmacy, a take-out joint and the Wewak Christian Bookstore. Throngs of pedestrians crowd along its bustling sidewalks during the mornings and early afternoons (fig. 4). People of all ages walk with great or little purpose while talking to companions or on their mobile phones. But, in addition, people stand around, or sit on stoops, talking with kin or "mates," as they watch the informal parade. Meanwhile, vendors hawk credit units for mobile phones, cigarettes and batteries. The occasional evangelist, encircled by a willing, or at least entertained, audience, may preach through a bullhorn. The congestion builds up all week and culminates on Friday and Saturday mornings, when townspeople combine with villagers who have come into Wewak for the weekend market. The sidewalks, whose potholes, as a reflection of the postcolonial state, go unpatched, test agility and punish inattention. People fear pickpockets, whose chances benefit from the bottleneck and the disrepair. Do the stoops and sidewalks offer space for the voices of the "public sphere" to debate the issues of the day?

The roads are also jammed, at least through mid-afternoon by which time everything begins to subside. At one end of the main street is a new police station and the town market, where fresh produce, smoked fish, local tobacco, together with crafts, are sold every morning. The market draws vendors, women mostly, from near and far in the province (fig. 5). A simple, open-air affair consisting of several, long, roofed rows of cement floors and tables, it was rebuilt from scratch in 2010 and named for Laura Martin, an Australian woman who, along with her husband, Frank, were much admired, longtime residents of Wewak (arriving in 1952). It is, needless to say, a

5. Wewak Hill is the original site of the village of Viaq, for which the town is named. The hill then became the colonial headquarters (Fleetwood, 1984: 20). 


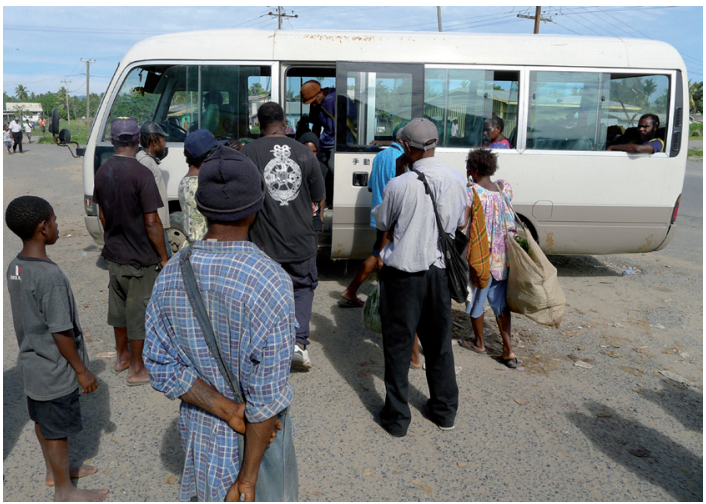

Figure 3. - At a bus stop, 2012 (C) David Lipset)

center of exchange and goods. But is it a public sphere where issues of the day may be discussed? The provincial radio station, its neighbor, might be said to be. At the end of the main street opposite the market is the Post Office, which is at once a relic of the colonial state and now an outpost of the postcolonial state. As there is no delivery, middle-class representatives of churches and businesses gather here to pick up their mail. Is this a public sphere?

The sociology of the town more or less follows the landscape. Wewak Hill and Kreer Heights are adorned with comfortable houses, with large, well-tended grounds, and stunning views of the bay area. Here, middle-class households, consisting of extended families, who are either Papua New Guineans, expatriate business people from Asia and Australia, or missionaries from the USA and elsewhere, are serviced by plumbed water, electricity and private trash collection. They live inside gated properties protected by private security guards and attack dogs (Lusby, 2014; Sharp et al., 2015). These properties are either owned freehold or they are employment entitlements, for example of bank managers who rotate through town every few years and then are moved onto another branch in the country. Everywhere else, that is to say, along the flats below, the town is populated by peri-urban, or squatter, settlements.

\section{Peri-urban Wewak}

Recent migrants to town, unlike the Highlanders living in Port Moresby in the early 1970s, do not avoid voluntary associations but nonetheless prefer to keep to their own company (Strathern, 1975; Koczberski et al., 2001). There are also longterm residents, who may still identify with natal villages, but have become townspeople, with adult

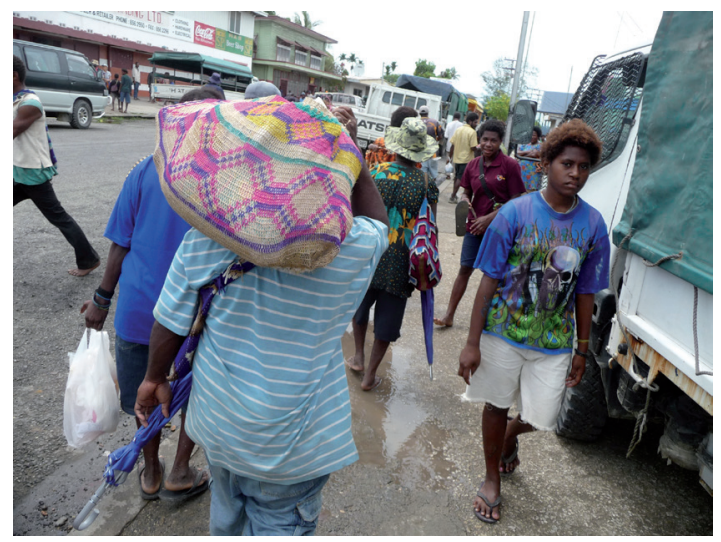

FIgURE 4. - On the sidewalk of the main street in Wewak, 2014 (C) David Lipset)

children raised there, adult children who are now employed in Wewak or elsewhere in the country. Intertribal marriage is commonplace. Such urban children grow up speaking Tokpisin and English rather than their vernacular languages. The periurban family is based in classificatory Hawaiian terminology. Grandparents and grandchildren call each other bubu, which is a contraction of tumbuna. Children are pikinini man and meri. Parents are papamama. Mothers' brothers and fathers' sisters are kandere and affines are called tambu. Male siblings are all brata and female siblings are sista. Main activities are preparing to go to work, getting children to school, going to market, etc. In the late afternoons, after school children return home, kin eat together and participate in voluntary organizations, such as church and athletic groups. Adults may play cards or go drink and play darts with intertribal "mates" and "friends" (Tokpisin, poro or lewa). However in addition to daily life, household members must also be ready at a moment's notice to respond to the sporadic needs of urban and rural kin at "home" for remittances, particularly in support of mortuary rites (Lipset and Silverman, 2016). In other words, peri-urban townspeople must balance multiple loyalties and commitments.

Figure 5. - Murik market women selling smoked clams, 2014 (C) David Lipset)

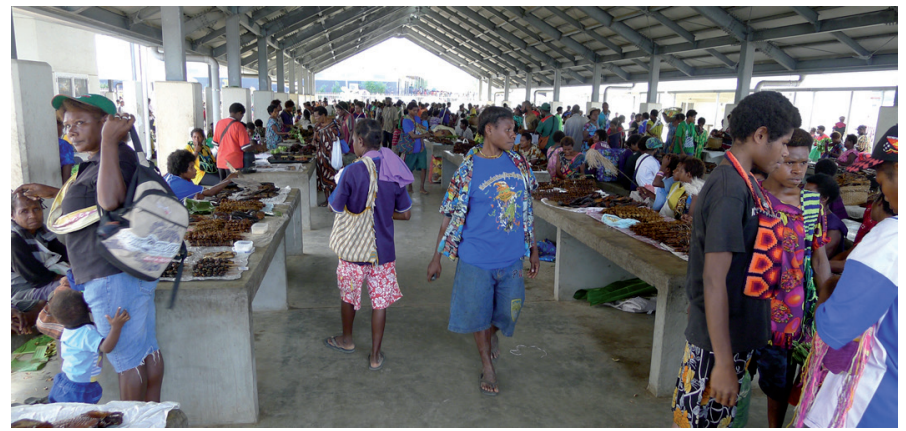




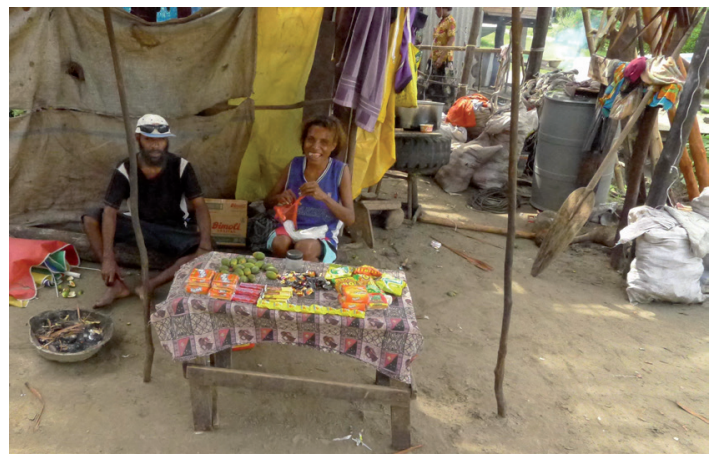

Figure 6. - Stall in front of peri-urban, Murik house, 2014 (C) David Lipset)

There are basically two kinds of peri-urban communities in Wewak, squatters' camps and the Compounds. The former consists of dense clusters of ramshackle, mostly bush-material houses which domicile large, extended families, with a great many young children (Goddard, 2001; Rooney, 2015). They re-constitute small tribal, or ethnic, enclaves, enclaves that to a certain extent sustain social categories of their villages of origin. For the most part, the households in these camps domicile a mix of long term residents and newly arrived families and temporary guests, village kin who are sometimes called pasingia in Tokpisin. The legitimacy of these settlements' claims to the land they occupy, which sometimes arose from pre-contact, hereditary trading partnerships (Lipset, 1985: 84), or else has been negotiated more or less de novo, is often in dispute with customary landowners who see them as little more than squatters' camps. Moreover, the township provides them no services, other than piped water, for which a monthly fee is collected.

The second kind of peri-urban settlement, which is perhaps slightly more legitimate, and somewhat more spacious and permanent than the squatters' camps is set in the remnants of "native labor compounds" that were built in the postwar era by the Australian Administration to house employees working as drivers, clerks, etc. The Compounds, whose neighborhoods are inhabited by a random intertribal mix of households, do receive both water and electricity from the city, but no sewage or trash collection. Here too, one finds longtime townsmen who raised families as well as temporary guests from the villages. But the legitimacy of the land claims of these households is also contested and subject to recurrent government plans to raze them in favor of expanding the commercial center of the city.

Like the tenuous relationship of settlements to the infrastructure of the township, the peri-urban household relies on a mix of informal and formal labor. The household economy draws on salaries distributed on a fortnightly pay cycle, more often than not to men, and profit made by individual entrepreneurs, in particular, by women manning stalls under umbrellas (Sharp et al., 2015; Gibson, 2013; Barber, 2003). One sees stalls everywhere - within settlements, along the street, at small, satellite markets that are overseen by the township (fig. 6). The goods women sell may be store-bought, such as batteries and cigarettes, and resold, or they may be imported from the villages, as in betel nuts, or, they may have been bartered for, cooked and sold, as in the case of exchange with sailors on the trawlers anchored in the bay who will trade frozen tuna for liquor, or mobile phone credits, or other services.

Attitudes about the moral quality of urban life bear upon the contested legitimacy of the nationstate. The main concerns are crime, inebriated youth, and the ineffectiveness of postcolonial government (Spark, 2014). Aspects of urban life people appreciate are access to the market and stores, the availability of healthcare, and the proximity of employed children. Women appreciate freedom, but have fears for their security (Demian, 2016).

Figure 7. - Murik settlement at Number Two Bay, 2012 (@ David Lipset)



\section{Peri-urban Murik in Wewak}

The Murik Lakes are a large system of mangrove lagoons located at the mouth of the Sepik River; and basically they constitute its estuary. The pre-contact Murik economy consisted of a small-scale fishery that was supplemented by year round intertribal trade for sago flour and garden produce with 


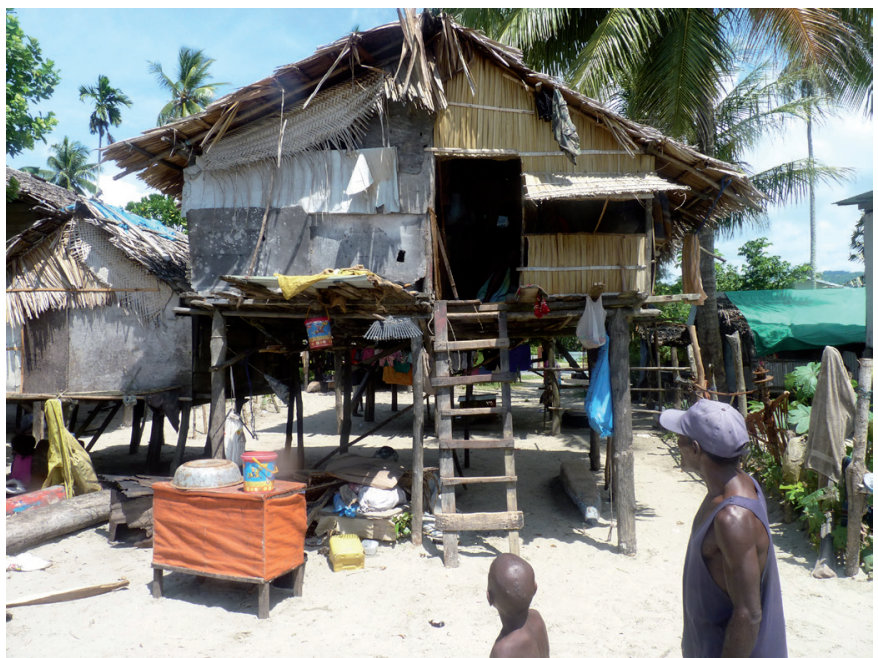

Figure 8. - Murik settlement at Kreer Camp, 2014 (C) David Lipset)

inland villages and seasonal overseas voyages on outrigger canoes to export Murik baskets and folk theater in exchange for pigs. Before contact, Wewak was merely one port in the latter regional network that arose from trading partnerships established there during the Murik migration from the middle stretches of the Sepik River. As the Murik economy shifted during Australian administration (1918-1975), it became partially integrated with colonial modernity, with the state, its currency and Western education, gods and goods. Wewak became a regional center, or central place, offering itself as the principle market for Murik fish (fig. 5).

In the later 1950s, three settlements (fig. 1) were established in agreement with the hereditary trading partners mentioned above (Somare, 1975). They formed around employed migrants who worked for the colonial administration or for businesses in town. Like the rural Murik villages, each one was located on the beach and to a certain extent reconstituted village social boundaries in these peri-urban settings some 40 miles west of the Murik Lakes. The three camps, one a bit east of Kreer market, the second just inland from Meni beach and the third one, called Number Two Bay, on an island slightly to the west of the town market, are comprised of permanent and semi-permanent Murik households (fig. 7). A few other Murik households are also scattered in middle-class parts of town, or in the Mangrove Compound, the occupants in which are not middle-class but are somewhat more comfortable than the "grass roots" citizens of the squatters' camps. The point is that peri-urban Murik society has become a permanent internal (rather than international) diaspora to rural kin; and so Murik townspeople today regard themselves as urban villagers, whose identities emerge in certain contexts as both/and.
One hears, for example in connection with dance performances at shows, of "village Karau" and "town Karau."

During the era of rising sea-levels that began to erode Murik beaches around 2007, the population of Murik settlements in town started to expand (Lipset, 2011, 2013, 2014). I did a household census of two Darapap village camps, one at Kreer Camp and the other at Meni Village which documents this development. The population of Kreer camp expanded from 64 in 2001 to 160 in 2014 while Meni village grew from 13 in 2001 to 197 in 2014 (fig. 8 ).

Lacking institutionalized intratribal organization, Murik townsmen recognize and acknowledge other Murik through personal networks, based in face-to-face, kinship relations and ritual obligations. In addition, they have intertribal relations based in hereditary trade partnerships, proximity to neighbors, intertribal marriages, occupational history, school ties and voluntary associations in church. These relationships form a loose moral community, one to which they feel and fulfill obligations of various kinds that derive from a combination of rural and urban ties and norms.

\section{Mobile phones as public sphere}

In a useful essay, Robbins called critical attitudes expressed by Urapmin people about PNG, "negative nationalism" (1998: 104). He argued that among this remote and isolated upper Sepik community in which he worked during the early 1990s, ambivalences about national identity were encouraged or even caused by "translocal" ideologies such as Christianity and ideas about race rather than from actual relations with the nation-state. The Urapmin condemned PNG because it was a morally deficient "nation of black people" who lacked self-control and agency in any number of ways (Robbins, 1998: 111-112). For the Urapmin, the only redemption they could imagine from such a modernity was in millennial Christianity, the white man's religion. Peri-urban Murik also hold negative views of the nationstate, and by extension the Papua New Guinean modernity in which they live. But what I now want to go on to do is discuss the extent to which they express that criticism in terms of mobile phone use rather than race and Christianity.

For example, a senior man of no particular religious commitment, but who is old enough to have had a career during the late colonial period, made the following observation to me about 
the ethos of urban life in contemporary PNG. Society in Wewak town had become unsafe and immoral. This normless situation may have had racial undertones. But explicitly, he held it up this condition as the outcome of a weak legal system.

\begin{abstract}
"Under colonial rule, there were strong laws. We were not allowed to drink. Now, we use mobile phones in the wrong way, to stage holdups and murders [...] Somebody, say you, goes the bank. 'They' watch and call their friends to block your escape routes, and rob you. Many men have been killed because of mobiles. Two white missionaries, and one of their wives, were robbed by the Windjammer [Hotel] this way."
\end{abstract}

In other words, the city, its banks and hotels, are beset by what Durkheim would have called anomie (1966); there is a normless element in society which has become empowered by mobile phones. Why? Not explicitly because the state is run by indigenous blacks. But rather because it fails to administer the law. Mobile phones, "used in the wrong way," enable criminals to plan and stage attacks, even against presumably expatriate men and women of God. Such a break from moral order would seem to be exceptional enough to stand as a signifier of collective unruliness in the nation. The "we" the informant imagines is a nation that has become more vulnerable to dangerous networks.

Another charge commonly associated with mobile phones alleges that the state does not merely enforce its laws adequately but that politicians are thieves. A senior man contended that

"[g]overnment ministers employ youth gangs to stage bank robberies. ${ }^{6}$ They organize their crimes via their phones."

The state, in this view, is not a politically neutral, third party that legislates on behalf of the common good. Its leadership is rather illegitimate and employ raskols, the young, urban hoodlums who began to imperil the streets and highways of the nation in the 1980s (Harris 1988, Goddard 1992, 1995, Sykes 1999). Neither politicians nor their delinquent supporters were viewed racially in this accusation. Instead, the postcolonial state is portrayed as a culpable kind of pirate sovereignty (Sundarum 2010).

Perhaps, the most oft-stated indictment of mobile phones has to do with the damage they are said to inflict upon conjugal life, which is to say, to marriage in the nation (see also Sullivan 2010). The new technology is seen to enable illegitimate, sub-state relationships (Hijazi-Omarai and Ribak, 2008). I collected many reflections about the purported tie between the new technology and infidelity.

"Before, men and women [in villages] used third parties to carry messages to arrange to meet [a lover]. [...] Now [in town] old men, married men, young men, students are all spoiled. They all have access. They commit adultery by mobile."

That is, what has the freeing up of the person from face-to-face space and time resulted in? What else has it done to the urban landscape? The diffusion of mobile phones, particularly, in this informant's view, has democratized men's capacity to arrange adultery. No longer must anyone rely on a human go-between. No longer must that party (ego's joking partner in Murik culture) be compensated for their services. The new technology has enabled an ego-centered network that has extended the id, according to this view. And, not surprisingly, it has given rise to a complementary, poignant kind of illegitimacy. Thus, a second informant claimed that:

"young women [...] get pregnant easily and quickly because of mobiles. They go the hospital to give birth and are asked who is the father? They call the name of a grandfather, not the father."

Reproduction in digital society is said to take place by means of digital conception which is illicit and covert (Zimmer-Tamakoshi, 1993: 71; see also Spark, 2010, 2014). Illegitimate children are reproduced during affairs and the hospital birth becomes a site of pretense rather than matrimony. Across the nation, more generally, the impact of mobile phones on marriage is depicted as giving rise to promiscuity rather than monogamy. A third informant offered an account of the following incident of digital adultery:

"I saw a fight at the bus stop [fig. 3]. A woman had been working at home when she got a call from a boyfriend [...] Her husband was home. [She] gave the phone to their daughter who said "hello" to the caller and put the phone on speaker. The husband heard the voice of his wife's boyfriend who said, 'Hurry up. I'm at the bus stop.' The husband raced to the bus stop and attacked his wife's boyfriend there. I saw it. The wife also [suffered consequences] and got into big trouble."

Here, mobile phones enabled egocentric networking, violence and marital conflict. But this is private life that has spilled out into the public eye. Apparently, however, illegitimate desire is sometimes linked to the nation and the state. I was sitting with several men in the yard of the household

6. Banks require that customers turn off their mobile phones while doing business.

7. Others, such as Sullivan (2010), have reported the apparently widespread phenomenon of what is termed in Tokpisin, "gas paia" calls. These are random, anonymous, prank calls by young men in the hope of just getting to hear a woman's voice on the line 
to be discussed below. We were discussing how incriminating incoming and outgoing call lists may appear to spouses. One senior man mentioned that he had only just the day before observed:

"a provincial administrator run by here, chased by his wife,"

who was furious at him after having checked the call lists on his mobile phone.

The new social technology is clearly viewed as increasing moral indeterminacy in relationships, making social life more unpredictable and one's confidence in others less reliable. Trust, the indispensible precondition of domestic and national legitimacy, is weakened (Seligman, 1997). Thus an informant made an observation about how mobile phones have affected his expectations about the relationship of speaker to space, and perhaps, to moral order, more generally (Townsend, 2000: 3). When

"people [talk] on their mobile phones," he presumed, and they "say they are in one place..., they are elsewhere. They lie. They say they are at the bank when they are at the hospital."

For Habermas, citizens, at least of a certain class and gender, began to assemble and talk rationally in the "public sphere" about the state and society in $18^{\text {th }}$ century Europe. The "public opinion" they formulated raised critical questions about the legitimacy of political authority under which they lived. However it is useful to recall that for the later Habermas (1996), the "public sphere" need not exist in any identifiable location. It became fluid and was not conceptualized as a space in which

"a certain kind of communication could take place, but a space generated by a certain kind of communication" (Hirschkop, 2004: 51)

As a communications technology whose distribution in the city is virtually universal, and provokes citizens to make anxious judgments about the legitimacy of the postcolonial nationstate, I want to view mobile telephones as a kind of portable public sphere in PNG. This is an imperfect theoretical move, I concede. But I think it will allow me to draw some conclusions about how the Melanesian "public sphere" differs from what Habermas saw in Europe, the relationship of public and domestic groups being rather different in PNG.

Having discussed how mobile phones give rise to criticism of the nation-state, I now turn to legitimate mobile phone use in Wewak town, and by extension, in what is claimed to be normative society. I analyze data collected from incoming and outgoing call lists that were generated over a three-day period in August 2011 on the phones of one household.

\section{Mobile telephony in a peri-urban, Murik household (August 2011)}

Wanuk and Bonowai were a senior, Murik couple whose peri-urban household might be categorized as overlapping between grass roots and lower middle-class, by PNG standards (fig. 9). They live in a deteriorating part of Wewak town called the "Compound," or the "Mangrove Compound" where, as I say, government workers used to be housed during the Australian colonial period in the 1960s. Today, household members in the "Compound" are no longer employed exclusively for the state, although many still are. They live there in intertribal, or interethnic, neighborhoods, pay no rent, but do not own the property on which their houses stand. From time to time, the government announces plans to relocate everyone, raze their houses, and expand the commercial zone of the city into this area. But as of 2017, nothing has come of such plans.

Wanuk was a retired storehouse clerk. His wife Bonowai did little things in the informal economy on a regular basis, like selling cakes to a former Chinese employer, whose children she once nannied. Their household, which received running

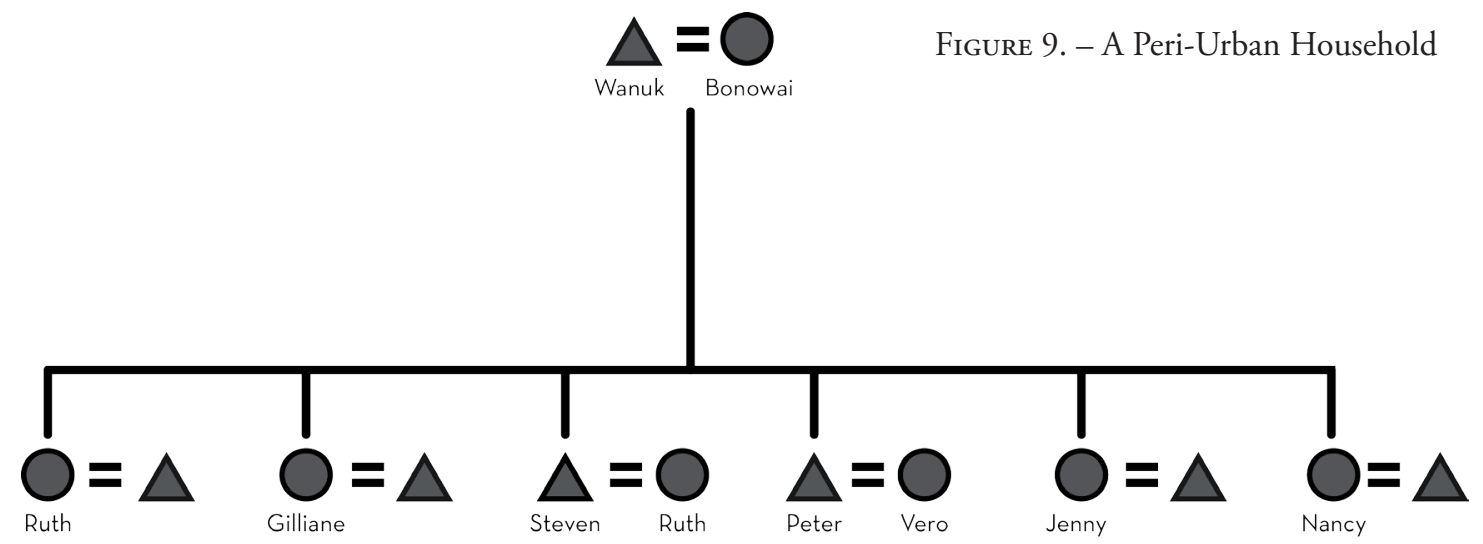




\begin{tabular}{|c|c|c|c|c|c|c|}
\hline Name & \# of Calls & Kin & Non-kin & Sex & Age & Status \\
\hline W & 8 & 8 & n/a & M & $70 s$ & Retired clerk/grandfather/father/husband \\
\hline B & 10 & 10 & n/a & F & $60 s$ & Grandmother/mother/wife \\
\hline N & 2 & 1 & 1 & F & $30 s$ & Daughter/mother \\
\hline J & 5 & 3 & 2 & F & $30 s$ & Daughter/mother \\
\hline S & 5 & 3 & 2 & M & $40 \mathrm{~s}$ & Pastor/Son/Father/Husband \\
\hline P & 4 & 3 & 1 & M & $40 \mathrm{~s}$ & Hospital Tech./Son/Father/Husband \\
\hline V & 3 & 3 & n/a & F & $30 s$ & Daughter-in-law/Wife/Mother \\
\hline N & 1 & 1 & n/a & M & $60 s$ & $\begin{array}{c}\text { Wanuk's brother/retired driver/ } \\
\text { Regular Guest }\end{array}$ \\
\hline S & 21 & 10 & 7 & M & $60 s$ & $\begin{array}{c}\text { Bonowai's brother/semi-employed, retired airlines } \\
\text { employee, regular guest }\end{array}$ \\
\hline
\end{tabular}

TABLE 1. - Household phone calls

water from the city, as well as electricity, was made up of a cluster of small, bush material buildings that encircled a little, central house made of aluminum siding. In 2011, the household consisted of Wanuk and Bonowai, two married daughters, Nancy and Jenny, who lived nearby and visited daily, and two sons, Steven and Peter, who lived with them together with their wives and children (fig. 9). The two sons were both employed. Steven was a pastor of a small evangelical church, whose building was located on household property, and Peter worked as a technician in the town hospital. In addition, two other married daughters, a bank manager and a teacher, lived in staunchly middleclass parts of town, but remained active presences in the household.

All adults and teenagers in the household owned a phone. Collating calls made by the adults during the three-day period in question (see Table 1), I made a distinction between calls made to kin and calls made to nonkin. It is clear from these data that most calls in the sample were made to family members. Amid much else that people were talking about--the Pastor was organizing work on the church building, a boss called trying to locate a daughter's husband, a mother wanted to send a child to buy something from a vendor, a husband rang to request money from his wife, old childhood friends called to check on the well being of members of the family - calls were made in connection with two particular events, the homecoming of Bonowai and a bad car accident in which Peter was involved. I want to discuss the use of mobile phones in the context of these two incidents in some detail.

\section{Bonowai's Homecoming}

In August 2011, I hired a little 23 foot banana boat to travel from town down the 40 mile coastline to the Murik Lakes in order to do some research in the villages for a few weeks. Bonowai, along with several other people, accompanied me. Leaving Wanuk, her husband, in town, she went to visit an elderly sister. The Murik Lakes receive no signal, except in a few fleeting spots at certain times of the day. So on the way back, when we got close enough to the point where the network is known to become accessible, Bonowai switched on her mobile phone and called Wanuk, her husband, to arrange for pick up (fig. 10). He immediately rang a sister's son, who was a bus driver, and asked him to collect us at the beach where we would put ashore. Wanuk also called a daughter to tell her that her mother had gotten back from the village. Soon enough, another daughter rang her father to ask if Bonowai had brought back any sandcrabs, the Murik Lakes being known for their shellfish. Two junior affines, a daughter's husband and a son's daughter's husband, also called Wanuk to ask about seafood. "They saw me return," Bonowai said. "They all like to eat smoked clams" (fig. 5).

Her firstborn daughter also rang to request that her mother prepare clams with sago breads, a delicacy to urban Murik taste. But Bonowai said "she was tired from all the travel and didn't want to cook," the daughter complained. The next day when Bonowai called back, the daughter refused to answer. "She was angry... about clams," Bonowai told me. "She didn't take the call. The phone rang for nothing. 'Why hadn't Mother cooked for me?,' she asked herself. So she didn't answer the phone" (see Donner 2007).

Permit me to make a couple of comments about Bonowai's homecoming. I want to contrast the legitimate purposes to which mobile phones are put to use in it with how use of the new technology was criticized for enabling immoral, egocentric networks. All of the calls were obviously made within one domestic, peri-urban network, a single family. They were, in this sense, expressions of private, not public, interests. But most significantly, they were all made for legitimate purposes. They 


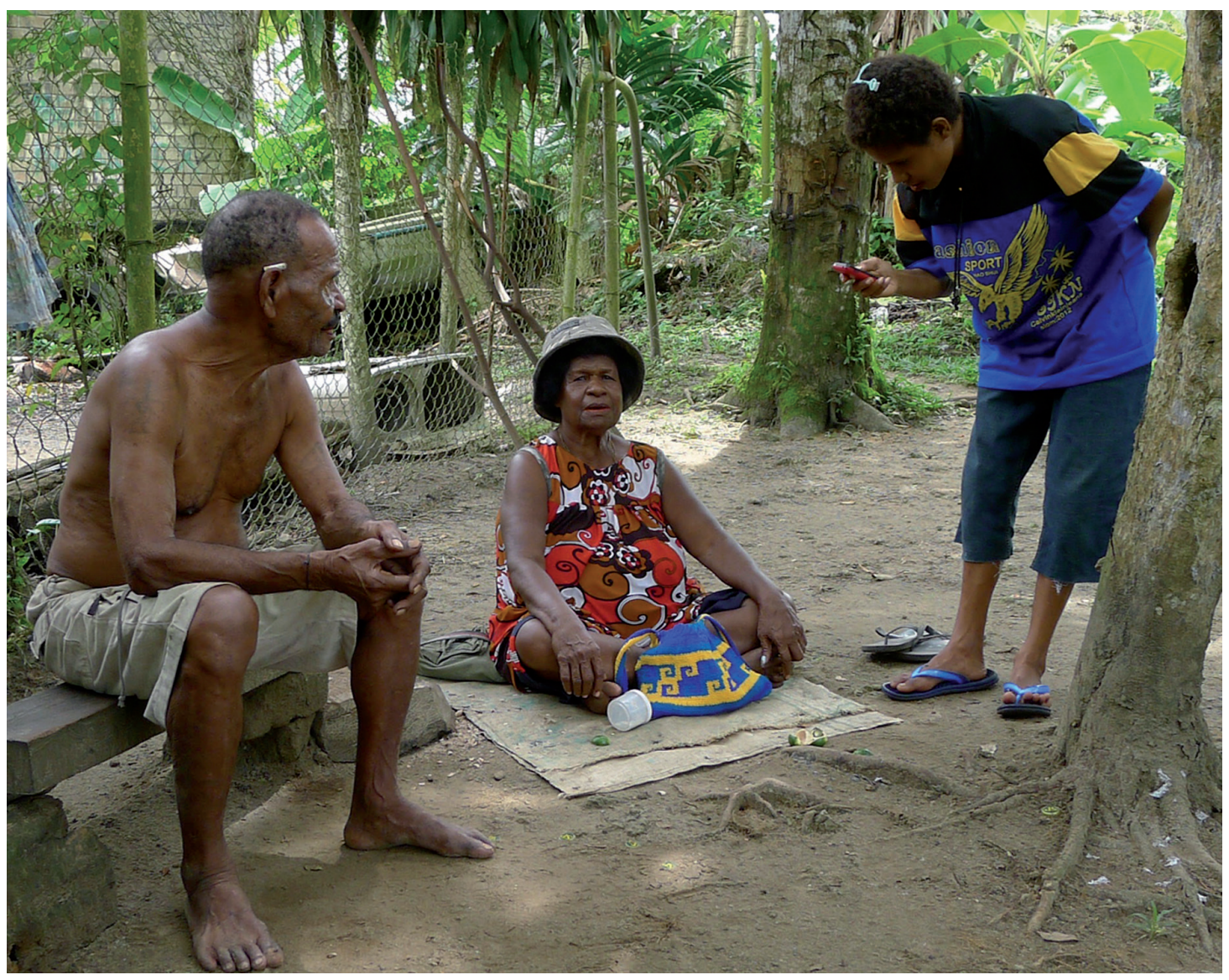

FIgURE 10. - Wanuk, Bonowai and a granddaughter with mobile phone, 2014 (@ David Lipset)

were all made within normative role expectations of a Murik kin group. Bonowai's initial request to her husband for pick up, was relayed to a nephew, and the news of her return was announced in calls to daughters, and then, in response, they made instant requests for Murik delicacies. This is normative communication in a taken-forgranted world of ascriptively-based obligation and support, a world of trust and convention. Even the perceived irritation of the daughter upon maternal refusal, or non-compliance, and her sulky, sullen withdrawal, are no less normative expressions of Murik anger and frustration. ${ }^{8}$ All of which is to say that these calls, which were made in a personal rather than a public register, seem to suggest that in this peri-urban sector of the nation, collective efforts of the domestic group to coordinate action its social life are a legitimate topic of phone calls.

\section{A Crash}

A few days prior to Bonowai's homecoming, her son Peter, a middle-aged, lab technician at Boram hospital, was riding back to Wewak in a truck from the Sepik hinterlands when the vehicle careened off the Sepik Highway and landed in a river, instantly killing the driver and three passengers, as well as injuring several others (fig. 11). Kin and affines were still calling about the accident after Bonowai's return from the Murik Lakes. At one point, she received a call from her husband's elder brother's son who wanted to speak to Peter about it; and I saw Bonowai hand her phone to him. A young nephew also called Wanuk to inquire about the condition of his "Uncle Peter" that same day. "He heard the news of the accident," Wanuk told me, "and... worried." A son of one of the injured passengers called his "Auntie Vero," Peter's wife, to report that they would be filing a claim for compensation from the government. One of Peter's classificatory brothers called to report that a mutual friend of theirs was starting to collect contributions on behalf of the accident victims. Another man rang to relate that he had given money to one of his co-workers at the hospital, who had been hurt. Another co-worker called Peter for news about the accident, and to ask about funeral arrangements.

8. At homecomings in the past, when outrigger canoes returned to villages laden with delicacies from overseas trading partners, I overheard bitter outbursts from kin who felt slighted by perceived inequities in the distribution of goods. 


\section{Four killed in Sepik H'way accident}

BY GABRIEL FITO

FOUR people are dead while others are being treated for severe injuries at the Wewak General Hospital following a car accident on the Sepik Highway, East Sepik, on Sunday.

Among those injured was official Kelvin Sugumat who had been accompanying a national court judge on circuit in Wewak.

Also on the injury list is a Wewak General Hospital staff.

Provincial police commander Snr Insp Vincent Pokas said the accident occurred at Pasik River when the PMV vehicle was returning to Wewak from Sengo village in Maprik on Sunday. Pokas said the truck went off the road before it reached the bridge and

landed in the river, instantly killing the driver and another passenger. A hospital dispensary staff later died on arrival at the hospital. Sketchy reports reaching the Wewak police station indicated that a fourth victim - a female passenger - had also died.

Police said the bodies of those who died were later taken back to the Maprik district hospital mortuary. Meanwhile, the national court sitting Wewak was suspended yesterday because Sugumat who was accompanying national court judge Justice George Manuhu on his circuit, was injured and admitted at the hospital. The court is expected to resume at 9am tomorrow.

FIGURE 11. - Newspaper account of the tragedy

One widely-reported benefit of legitimate mobile phone use is a subjective sense of security-a kind of moral boundedness, as it were, a moral boundedness that is said to accrue from being able to make a call for help during emergencies of sort or another (Katz and Aakhus 2002). In this instance, the use of mobiles phones in the aftermath of a tragedy enabled the circulation of information that allayed apprehensions and allowed for expressions of care and support. The technology created moral community in a legitimate, virtual space, among people, most of whom were kin but were supplemented by a few "co-workers." This incident, together with Bonowai's homecoming, clearly illustrate how mobile telephones are put to legitimate use in urban modernity in PNG. I would argue, however, that the calls that took place during the two events were not merely expressions of private interests. They simultaneously expressed voices of communitas in a deeply particularistic postcolonial nation. ${ }^{9}$

\section{Conclusion: a public sphere in peri-urban PNG}

Mobile telephones in urban PNG constitute a new kind of "public sphere," one that differs from that which Habermas imagined to have emerged in early modern Europe. It is not a distinct, institutionalized form of verbal and written communication. It is not located in any specific space in which citizens informally and unofficially gather to talk freely about issues of general concern and thereby form "public opinion" that might compel the state to reform itself. Nor, for that matter, does the discourse and practice it provokes and enables adhere to universal standards of logic and reason. Rather, in the communicational environment of the new nation-state, mobile phones, particularly in cities, enable communicative freedom in a virtual, or technologically constituted, space.

In contemporary PNG, the public sphere expressed in mobile phone discourse and use is incongruous. Its values are both universalist and particularistic. As signifier, mobile phones seem to provoke critique of the legitimacy of the nation and the state, a critique that entails implied normative standards and criteria of value that are transgressed. As social technology, mobile phone enables moral communication of a particularistic kind. That is, they enable assertions of affective regard or disregard for kin, as in the calls made and declined in the context of a mother's homecoming (Campbell and Park, 2008). ${ }^{10}$

For Habermas, the public sphere is an intermediate institution that exists in between the state and the private sectors of society. It may link one with the other. At the same time, he allows that there may be several kinds of public spheres (1996: 374). What is central in any of them is communication, or what he prefers to call communicative action (1996: 360). Castells et al. argue that:

"mobile communication [...] is adopted, adapted, and modified by people to fit their own practices, according to their needs, $[\ldots]$ interests and desires." (2007: 125)

Following both Habermas and Castells, I want to emphasize that mobile phones enable communicative action, and public spheres, which are culturally variable.

9. Note that Bonowai gave her handset to her son when her husband's elder brother's son called. Bonowai explained to me that the call had been made to her number because rates are less expensive between subscribers of the same company. Individuals own phones and numbers are not shared like land-lines. Peter took his mother's phone, spoke to his kinsman, and returned it to her, without comment or compensation. That is to say, as icons of individuation within the household and among kindred, they do not differentiate a proprietary self from a proprietary other.

10. Apparatgeist, or the spirit of the machine, is a notion developed to explain consistencies in social change that come out of the adoption and use of mobile phones and other personal communication technologies. According to Katz and Aakhus (2002), human beings share a universal orientation toward communication, which manifests in how we think about and use mobile phones. The symbolic nature of mobile phones is one of the most prominent areas of social change to which apparatgeist draws attention. What lies at the core of their framework is the increasingly personal nature of communication technology they term 'perpetual contact'. Similarly, Oldyzko's (2000) historical review of mediated communication reveals a traditional preference for interpersonal contact as opposed to person-machine or broadcast forms of communication. 
In the present case, I have shown that they are evaluated and used in ways that combine the universal with the particularistic, in other words, the public with the private. In the domestication of mobile phones in peri-urban Papua New Guinea, that is to say, not only do we hear rational voices, but they are part of an open-ended, contradictory commentary on a modernity-inthe-making.

\section{REFERENCES}

Barber Keith, 2003. The Bugiau community at eight-mile: an urban settlement in Port Moresby, Papua New Guinea, Oceania 73, pp. 287-297.

Bell Joshua, 2016. Everything Will Come Up Like TV: Death in an Age of Uncertainty in the Purari Delta, Papua New Guinea, in David Lipset and Eric K. Silverman (eds), Mortuary Dialogues: Death Ritual and the Reproduction of Moral Community in Pacific Modernities. New York: Berghahn, pp. 208-233.

Castells Manuel, 2005. The Network Society: From Knowledge to Policy, in Manuel Castells and Gustavo Cardoso (eds), The Network Society: From Knowledge to Policy, Washington DC: Johns Hopkins Center for Transatlantic Relations, pp. 3-22.

Campbell Scott W. and Yong Jin Park, 2008. Social Implications of Mobile Telephony: the rise of personal communication society, Sociology Compass 2, 2, pp. 371-87.

Connell John, 1985. Migration, Employment and Development in the South Pacific: Country Report No. 14 Papua New Guinea, Noumea, South Pacific Commission and International Labour Organisation.

—, 1997. Papua New Guinea: The Struggle for Development. London: Routledge.

DalsgaArd Steffen, 2016. The ethnographic use of Facebook in everyday life, Anthropological Forum 26 (1), pp. 96-114.

Demian Melissa, 2016. Making women in the city: notes from a Port Moresby boarding house, Signs: Journal of Women in Culture and Society 42 (2), pp. 403-425.

Donner Jonathan, 2007. Recent approaches to mobile use in the developing world: a review of the literature, The Information Society 24: 3, pp. 140-159.

Durkheim Émile, 1966 (éd. or. 1897). Suicide: A Study in Sociology, John A. Spaulding and George Simpson (trans.), New York, Free Press.
FILer Colin, 2013. Asian investment in the rural industries of Papua New Guinea: What's new and what's not?, Pacific Affairs 86 (2), pp. 305-326.

FleEtwood Lorna, 1984. A Short History of Wewak, Wewak, Wirui Press.

Foster Robert, 2002. Materializing the Nation: Commodities, Consumption, and the Media in Papua New Guinea, Bloomington IN, Indiana University Press.

Gewertz Deborah and Frederick Errington, 1999. Emerging Class in Papua New Guinea: The Telling of Difference, Cambridge, Cambridge University Press.

Gibson J., 2013. The labour market in Papua New Guinea (with a focus on the National Capital District), Unpublished technical report on the 2009/10 Household Income and Expenditure Survey."

Goddard Michael, 1992. Big-man, thief: the social organization of gangs in Port Moresby, Canberra Anthropology 15 (1), pp. 20-34.

—, 1995. The Rascal road: crime, prestige, and development in Papua New Guinea, The Contemporary Pacific 7, pp. 55-80.

-, 2001. From Rolling thunder to reggae: imagining squatter settlements in Papua New Guinea, The Contemporary Pacific 13, 1, pp. 1-32.

Habermas Jürgen, 1991/1962. The Structural Transformation of the Public Sphere: An Inquiry into a Category of Bourgeois Society, Thomas Burger (trans.), Cambridge MA, The MIT Press.

-, 1996. Between Facts and Norms: Contributions to a Discourse Theory of Law and Democracy, W. Rehg (trans.), Cambridge, Polity Press.

HARRIs Bruce, 1988. The rise of rascalism: action and reaction in the evolution of rascal gangs, Discussion Paper 54, Port Moresby, Institute of Applied Social and Economic Research.

Hijazi Hiyam and Rivka Ribak 2008. Playing with fire: on the domestication of the mobile phone among Palestinian teenage girls in Israel, Information, Communication and Society 11 (2), pp. 149-66.

Katz James E. and Mark Aakhus, 2002 (eds). Perpetual Contact: Mobile Communication, Private Talk, Public Performance, Cambridge, Cambridge University Press.

Koczberski Gina, George N. Curry and John Connell, 2001. Full circle or spiraling out of control? State violence and the control of urbanization in Papua New Guinea, Urban Studies 38 (11), pp. 2017-36. 
LIPSET David, 1985. Seafaring Sepiks: Ecology, warfare and prestige in Murik trade, Research in Economic Anthropology 7, pp. 67-94.

-, 2011. The Tides: masculinity and climate change in coastal Papua New Guinea, Journal of the Royal Anthropological Institute (ns) 17, pp. 2043.

-, 2013. Mobail: Moral ambivalence and the domestication of mobile telephones in periurban Papua New Guinea, Culture, Theory and Critique 54 (3), pp. 335-354.

—, 2014. Place In the anthropocene: a mangrove lagoon in Papua New Guinea in the time of rising sea-levels, HAU: Journal of Ethnographic Theory 4 (3), pp. 215-243.

—, 2016. The Knotted Person: Death, the Bad Breast, and Melanesian Modernity among the Murik, Papua New Guinea, in David Lipset and Eric K. Silverman (eds), Mortuary Dialogues: Death Rites and the Reproduction of Moral Community in Pacific Modernities, New York, Berghahn, pp. 81-109.

Lipset David and Eric K. Silverman (eds), 2016. Mortuary Dialogues: Death Rites and the Reproduction of Moral Community in Pacific Modernities, New York, Berghahn.

Lusby Stéphanie, 2014. Preventing violence at home, allowing violence in the workplace: a case study of security guards in Papua New Guinea, In Brief 2014/9, Canberra, Australian National University (ips.cap.anu.edu/ssgm).

Macintyre Martha, 2011. Money changes everything: PNG women in the modern economy, in Managing modernity in the Western Pacific, St Lucia, University of Queensland Press, pp. 90-120.

KeIr Martin, 2013. The Death of the Big Men and the Rise of the Big Shots: Custom and Conflict in East New Britain, New York, Berghahn.

Meyerson George, 2001. Heidegger, Habermas and the Mobile Phone, Cambridge un, Icon Books.

Oldyzko Andrew, 2000. The History of Communications and its Implications for the Internet (http:www.dtc.umn.edu/odlyzko/docl history.communications, accessed on 3 May 2016).

Oram Nigel Denis, 1976. Colonial Town to Melanesian City, Canberra, Australian National University Press.

Rashid Ahmed T. and Laurent Elder, 2009. Mobile phones and development: an analysis of IDRC-supported projects, The Electronic
Journal on Information Systems in Developing Countries 36, pp. 1-16.

Roвbins Joel, 1998. On reading 'world news': apocalyptic narrative, negative nationalism and traditional Christianity in a Papua New Guinea society, Social Analysis 42 (2), pp. 103-130.

Seligman Adam B., 1997. The Problem of Trust. Princeton NJ, Princeton University Press.

Sharp Timothy, John Cox, Ceridwen Spark, Stephanie Lusby and Michelle Rooney, 2015. The formal, the informal and the precarious: making a living in urban Papua New Guinea, SsGM Discussion Paper 2015/2, Canberra, Australian National University (ips.cap.aun. edu.au/ssgm).

Sinclair James, 1992. To Find a Path: The Papua New Guinea Defense Force \& the Australians to Independence, Vol. II Keeping the Peace 19501972, Brisbane, Boolarong Publications.

Somare Michael, 1975. Sana: The Autobiography of Michael Somare, Hong Kong, Niugini Press.

Spark Ceridwen, 2011. Gender trouble in town: educated women eluding male domination, gender violence and marriage in PNG, The Asia Pacific Journal of Anthropology 12 (2), pp. 164-180.

-, 2014. We Only get the daylight hours: gender, fear and freedom in urban Papua New Guinea, Security Challenges 10 (2), pp. 15-32.

Strathern Marilyn, 1975. No Money on Our Skins: Hagen Migrants in Port Moresby, Port Moresby and Canberra, New Guinea Research Unit, The Australian National University.

Sullivan Nancy, 2010. Fieldwork report in support of an environmental and social management framework for the World Bank supported Rural Communications Fund Project in East Sepik and Simbu Provinces, Papua New Guinea, Madang, Nancy Sullivan and Associates (https: //www. academia.edu/4492654/Fiedlwork_Report_ in_Support_of_an_Envrionmental_and_Social_Management_Framework_for_Rural_ Communications).

Sundaram Ravi, 2010. Pirate Modernity: Delhis Media Urbanism, New York, Routledge.

Sykes Karen, 1999. After the 'Raskol' feast: youths' alienation in New Ireland, Papua New Guinea, Critique of Anthropology 19 (2), pp. 157-174.

Zimmer-Tamakoshi Laura, 1993. Nationalism and sexuality in Papua New Guinea, Pacific Studies, 16 (4), pp. 61-97. 